\title{
cBio-Cementation of Sandy Soil through Bacterial Processing to Precipitate Carbonate
}

\author{
Layth K. Shannoon ${ }^{1}$, Mohammad A. Ibrahim ${ }^{2}$
}

\section{Authors affiliations: \\ 1) Civil Engineering Department, Al-Nahrain University, Baghdad- Iraq. lsahnnoon@gmail.com}

2) Civil Engineering Department, Al-Nahrain University, BaghdadIraq. moh env@eng.nahrainuniv.edu.iq

\section{Paper History:}

Received: $11^{\text {th }}$ Feb. 2020

Revised: $23^{\text {rd }}$ March 2020

Accepted: $16^{\text {th }}$ July 2020

\begin{abstract}
Bio-cement built on microbial induced carbonate precipitation MICP, be able to consolidate the loose grains and can applied for soil reinforcement. In this study, the performing of an ureolytic Sporosarcina Pasteurii for sand stabilization was estimated. The S. Pasteurii Could effectively consolidates sand particles through urea hydrolysis and the successive production of calcite. The bio improved sands had relative great compressive strength after 60 days exposure to bacterial cells injections cycles. The compressive strength of bio stabilized sands was reliant on the utilized cell concentrations and density of urea and $\mathrm{CaCl}_{2}$. High bacteria cell masses decreased the compressive strength. The optimal density of cell, was $\mathrm{OD}_{600}$ 0.5 , when cost and performance were taken into account. The study shows that bio cementation of sand built on microbial induced carbonate precipitation (MICP) has ability for the reduction of sand permeability through pore clogging with precipitated carbonate.
\end{abstract}

Keywords: Bio-Cementation, Compressive Strength, Permeability.

$$
\begin{aligned}
& \text { التعزيز الحيوي للترب الرملية من خلال النشاط البكتيري لترسيب الكاربونات } \\
& \text { ليث كاظم شنون ،محمد عبد الخالق ابراهيم }
\end{aligned}
$$

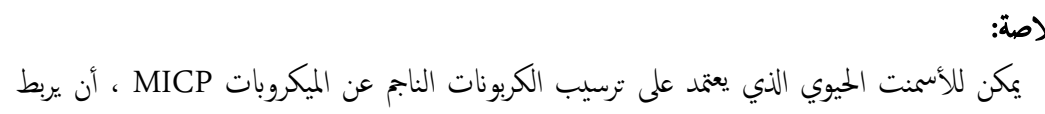

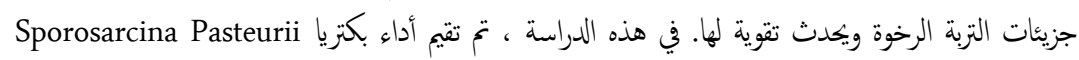

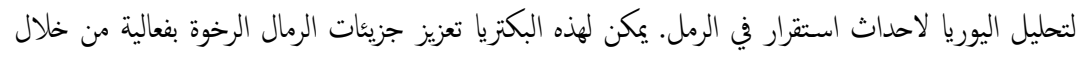

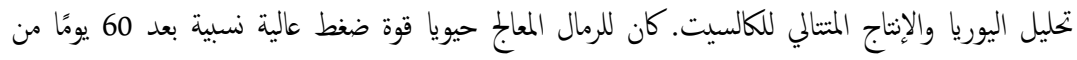

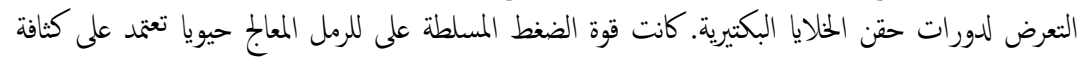

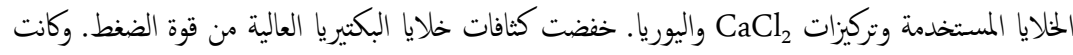

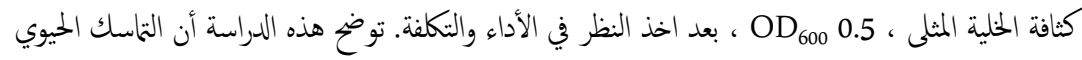

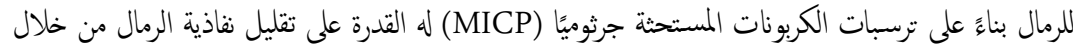

$$
\begin{aligned}
& \text { انسداد المسام بالكربونات المتزسبة. }
\end{aligned}
$$

\section{Introduction}

Mineral precipitation affected by microbial action in subsurface, frequently signified to a microbial induced carbonate precipitation (MICP), can be developed for a range of engineered applications involving the restriction of groundwater contaminants Fujita et al. [1], ground strengthening or changing properties of porous materials DeJong [2]; van Paassen et al.[3]; Whiffin et al.[4], and the formation of hydraulic barriers for functions such as improved expanding storage security of $\mathrm{CO}_{2}$ or oil recovery [Cunningham et al.[5].

Many bacteria are able of urea hydrolyzing, that can modify the moistening state of the creation water, and in the existence of calcium, may support the calcium carbonate precipitation Ferris et al.[6], 2003; Mobley and Hausinger[7]; Stumm and Morgan [8].
In earlier reports, excessive calcium carbonate precipitation was noticed nearby injection spots that could possibly lead to inhibited moving of nutrients which is undesirable influences on well injection process Fujita et al.[9]; Whiffin et al.[4]. Previously a bio mineralization mechanism can be counted field related, metal accumulation should be established to be controllable at a related scale as sustaining economic possibility Harkes et al.[10]. Controlling mineralization has been studied by estimating the reaction with transport, for example, changing injection strategies or injection speeds, operating the concentrations of reactant, expanding the number of actions, or governing the spreading of active bacteria [De Muynck et al.[11]; Harkes et al.[10]; Whiffin et al.[4], Mohammad et al.[12]. Furthermore, it has been stated that the forms and sizes of crystals shaped are influenced by the number and shape (planktonic or

NJES is an open access Journal with ISSN 2521-9154 and eISSN 2521-9162

This work is licensed under a Creative Commons Attribution-NonCommercial 4.0 International License 
attached) of cells, and so on the ecological conditions in nearby liquids can involve precipitation Achal et al.[13]; Tobler et al.[14]. Multiscale and wide cross corrective study on the probability of such a mechanism is answer for its successful application DeJong et al.[15].

Three split column tests were presented in order to: investigate the injection process that makes homogenous $\mathrm{CaCO}_{3}$ distribution along the bed of the column with different bacteria concentration.

This study then investigates the possible use of MICP built for sand stabilization and hydraulic conductivity. The effects of bacteria density, urea and calcium concentrations on sand stabilization have been tested, as one with performance under various bacteria concentration.

\section{Materials and Methods}

\subsection{Preparation of the Bacterial Cells.}

For the MICP procedure, Sporosarcina Pasteurii (American Type Culture Collection ATCC 11859) S. Pasteurii bacteria utilized in this study were cultured under aerobically batch environments in growth medium. The medium of growth was prepared by dispersing $5 \mathrm{~g} / \mathrm{L}$ peptone, $5 \mathrm{~g} / \mathrm{L}$ NaCL, $4 \mathrm{~g} / \mathrm{L}$ Yeast extract, $1 \mathrm{~g} / \mathrm{L}$ Beef extract and $50 \mathrm{ml}$ Urea Mixture in one liter of purified water. The mixture was put in autoclave at $121{ }^{\circ} \mathrm{C}$ for 15 minutes to execute any germs that might contaminate the growth of bacteria (S. Pasteurii).

The autoclaved solution was cooled to room temperature. Urea mixture was prepared by liquefying $10 \mathrm{~g}$ of urea grains in $50 \mathrm{ml}$ of purified water and sterilized using $0.25 \mu \mathrm{m}$ bacterium filter, then added to main growth solution and shacked until homogenized. The urea solution was added after autoclaving to prevent urea hydrolysis in high temperature.

\subsection{Bacteria Culture}

A bacteria culture was generated by transferring a small quantity of the S. Pasteurii lyophilized culture into $250 \mathrm{ml}$ of the culture medium next the making solution cultivated in incubator (under aerobic set conditions) at $25^{\circ} \mathrm{C}$ for 48 hours and allowing culture growth to occur. This mixture was cooled and kept at $4^{\circ} \mathrm{C}$ former to its use. The main culture medium was inoculated with the cells culture $(10 \% \mathrm{v} / \mathrm{v})$ and incubated aerobically under agitation at $30^{\circ} \mathrm{C}$ for 48 hours until the cells had reached maximum population (i.e. a stationary phase). After that the cells in the culture medium was harvested at $4^{\circ} \mathrm{C}$ by centrifugation for $10 \mathrm{~min}$ at $5000 \mathrm{rpm}$. The harvested bacteria were then washed twice with buffer of $0.1 \mathrm{M}$ sodium phosphate $\mathrm{pH} 7$ to eliminate metabolic waste and any metabolism yielded during the bacterial growth phase. 'Metabolism' belongs to all chemical results that occurred in the bacterial cells.

Metabolic wastes are substances that bacterial cells cannot use it (i.e. excessive or have lethal effect) and must be expelled before its use.

\subsection{Bacteria Counting}

To regulate and control the guessed bacteria concentration, a spectrophotometer method was used. UV-Spectrometer (Shimadzu 1800) Japan was employed for calculating bacteria. To investigate the concentration of bacteria cells, around $10^{8}$ cells $/ \mathrm{ml}$ was taken by dilution utilizing distilled water and counted by measuring the absorbance (optical density) of the solution operating a spectrophotometer at $600 \mathrm{~nm}$ wavelength. Using Equation below is for estimation the concentration of bacteria cells suspended in the solution culture corresponding to $\mathrm{OD}_{600}$ value (Ramachandran et al. [16].

$$
y=8.59 \times 10^{7} \times Z^{1.3627}
$$

Where $\mathrm{Z}$ is reading at $\mathrm{DO}_{600}$, and $Y$ is the cells concentration $\left(\mathrm{mL}^{-1}\right)$.

\subsection{Reagent Solution}

Calcium chloride, $\mathrm{CaCl}_{2}$ and Urea in different mole concentration were used as a reagent solution or cementation and nutrient solution. The reagent materials per liter of ions free water are $3 \mathrm{~g}$ Nutrient broth, $10 \mathrm{~g} \mathrm{NH} 4 \mathrm{Cl}, 2.13 \mathrm{NaHCO}_{3}$ (Sodium acid Carbonate), $0.25 \mathrm{~mol}=27.75 \mathrm{~g} \mathrm{CaCl}_{2}$ (calcium chloride) and $0.5 \mathrm{~mol}=30.03 \mathrm{~g} \quad \mathrm{CO}\left(\mathrm{NH}_{2}\right)_{2}$ (Urea), DeJong et al.[2]; Ferris et al.[17]; Y. Inagaki et al.[18].

\subsection{Soil}

The compatibility concerning the soil particle characters and the size of bacteria cells is significant factor for MICP process. The soil pores should have adequate size to permit the transportation of bacteria which $0.5-3.0 \mu \mathrm{m}$ in length, Mitchell and Santamarina [19], with $50-400 \mu \mathrm{m}$ stated as the best soil grain size range for bacterial movement in the pores, RebataLanda [20]. In the present study Karbala clean loose sand was used as a porous media in the batch samples and bench scale experiments.

Sand with mean particle size $\mathrm{D}_{50}$ equals to 0.403 $\mathrm{mm}$, the uniformity coefficient $\mathrm{C}_{\mathrm{u}}$ equals to 2.497 and the curvature coefficient $C_{c}$ equal to 1.224 . The sand particle size distribution curve was obtained from sieve analysis in accordance with ASTM D6913-04, is shown in Figure (1). The Figure (2) represents grains photo in scanning electron microscopy (SEM), which displays a regular sub rounded shape and the size of particles were medium to fine as tested at Physics department collage of science Al-Nahrain University. The specific gravity (Gs) of sand particles is determined using the pycnometer method as specified by ASTM D854-10 with value equals to 2.63 The values of minimum and maximum void ratios were tested according to ASTM D4254 and ASTM D4253, and it were for e min and e max equal to 0.588 and 0.857 respectively. Table (1) summarized the physical properties of the sand were used. The chemical properties and mineral compositions of the sand used were illustrated in Table (2). 
Table (1): Physical properties of Karbala sand utilized in tests.

\begin{tabular}{|c|c|c|}
\hline Parameter & Value & Text Mluthod \\
\hline Shyse & Sab roinded: & SEM \\
\hline Minent ompoutim & 3895, Quntz & EDS \\
\hline  & 0150 & ASTM DEI3 \\
\hline Effersive paticle gaze, Dos (mm) & ठक्रा & ASTM DEMS \\
\hline Mean particle sine Dw (trm) & 0.412 & ASTM DEA13 \\
\hline 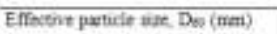 & 046 & ASTM DSPII \\
\hline Coethicienr of Laiformity, Ol & 20 & ASTM DE913 \\
\hline Coetriciene of Carvature, $\mathrm{Cc}$ & 1.08 & ASTM DESTS \\
\hline Sphofic presty, Ge & 2637 & ASTM DS5+10 \\
\hline Minimue roit ratib, om & 0587 & ASTM DA2SS \\
\hline Maxime void ratho, am & 0850 & ASTM D425a \\
\hline 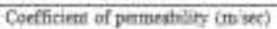 & 000158 & ASTM D D $856-15$ \\
\hline Bulk deatity $\left(g \circ \mathrm{cos}^{3}\right)$ & 1.09 & ASTM DT263 \\
\hline Porkitry, $=[S]$ & 359 & ASTM D 203.09 \\
\hline Orzamic matien $\left[c^{2}\right.$ ) & 6197 & A5TM D2974-14 \\
\hline
\end{tabular}

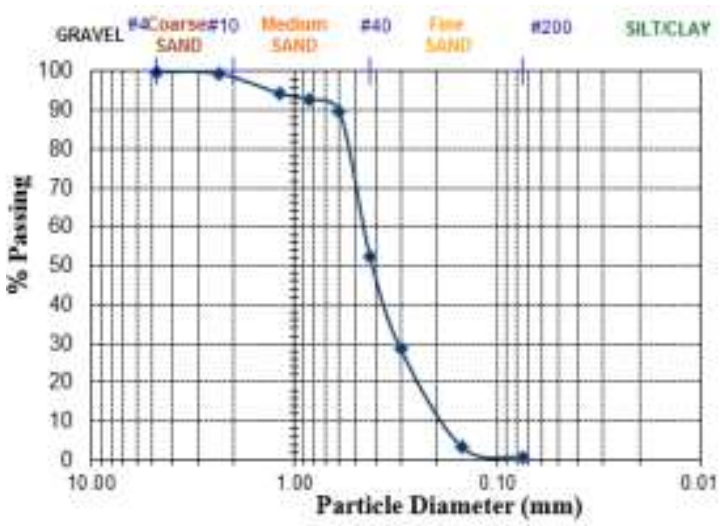

Figure (1): Sieve analysis grain size curve of sand used in this study

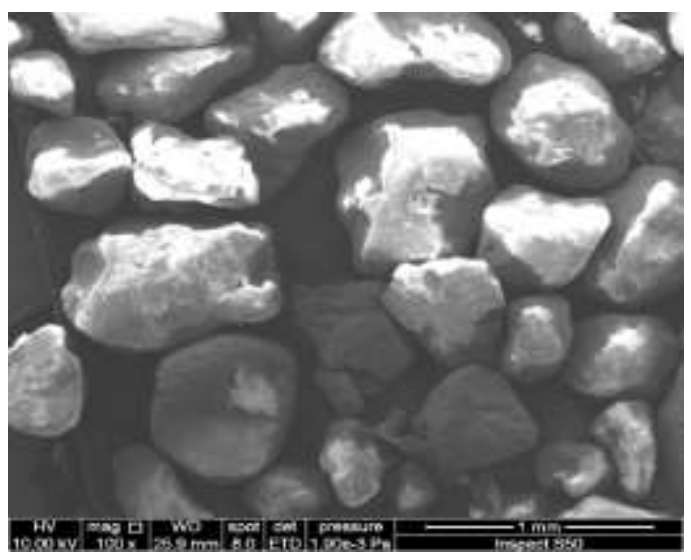

Figure (2): Photo represents the grains of sample in SEM

Table (2): Chemical properties and mineral composition of sand used.

\begin{tabular}{|c|c|c|}
\hline Characteristics & Value & $\begin{array}{c}\text { Analysis } \\
\text { method }\end{array}$ \\
\hline $\mathrm{SiO}_{2}(\%)$ & 98.3 & XRD \\
\hline $\mathrm{CaCO}_{3}$ & 0.042 & XRD \\
\hline $\mathrm{Fe}_{2} \mathrm{O}_{3}$ & 1.37 & XRD \\
\hline $\mathrm{MgO}_{2}$ & 0.019 & XRD \\
\hline $\mathrm{Al}_{2} \mathrm{O}_{3}$ & 0.15 & XRD \\
\hline $\mathrm{K}_{2} \mathrm{O}$ & 0.074 & XRD \\
\hline $\mathrm{Na}_{2} \mathrm{O}$ & 0.027 & XRD \\
\hline $\mathrm{P}_{2} \mathrm{O} 5$ & 0.018 & XRD \\
\hline
\end{tabular}

\section{Chemical Reactions}

During the existence of the urease enzyme, urea is hydrolyzed to provide carbonic acid and ammonia. The bacteria S. Pasteurii is able to produce great quantities of urease Ciurli et al.[21]. The successive protonation of ammonia to ammonium initiates $\mathrm{pH}$ increase, changing the balance of calcite precipitation/dissolution reacting to precipitation via rising the accessibility of the carbonate ion $\left(\mathrm{CO}_{3}{ }^{+2}\right)$.

$$
\begin{gathered}
\mathrm{CO}\left(\mathrm{NH}_{2}\right)_{2}+2 \mathrm{H}_{2} \mathrm{O} \stackrel{\text { urease }}{\longrightarrow} 2 \mathrm{NH}_{3}+\mathrm{H}_{2} \mathrm{CO}_{3} \text { ureolysis } \\
\mathbf{2} \mathbf{N H}_{\mathbf{3}}+\mathbf{2} \mathbf{H}_{\mathbf{2}} \mathbf{O} \leftrightarrow \mathbf{2} \mathbf{N H}_{\mathbf{4}}^{+}+\mathbf{2} \mathbf{O} \mathbf{H}^{-} \text {protonation of } \\
\text { ammonia } \\
\mathrm{H}_{2} \mathrm{CO}_{3}+\mathrm{OH}^{-} \leftrightarrow \mathrm{HCHO}_{3}^{-}+\mathrm{H}_{2} \mathrm{O} \text { acid dissociation of } \\
\text { carbonic }
\end{gathered}
$$

$\mathrm{Ca}^{+2}+\mathrm{CO}_{3}^{-2} \leftrightarrow \mathrm{CaCO}_{3} \downarrow$ precipitation dissolution of calcite.

The separation reactions are quick paralleled to ureolysis, precipitation and dissolution. Therefore, these are supposed to follow immediately and are included with balance coefficients. Slow on the uptake reactions are defined by utilizing rate expressions.

\section{Experimental methods \\ 4.1 Specimen preparation}

To perform a bio remediation and soil characteristics development, bacterial prepared solution was injected into soil sample. Clear acrylic tube columns (48 mm ID x $103 \mathrm{~mm}$ long, 186-mL) packed with sand. The tube columns were covered at both ends with solid O-ringed acrylic blocks $(80 \mathrm{~mm}$ x $80 \mathrm{~mm}$ x $10 \mathrm{~mm}$ thick) which were connected by four threaded steel rods. Fluid sampling ports where placed on top and the bottom blocks with an interior mesh deposit to avoid sand drip as shown in Figure (3). The insertion of solution to the fully saturated soil sample should be attained a uniform distribution along the specimen by using staged injection with retention period and it was accomplished through influent opening by following order O'Kelly et al.[22]: a. De-aired the sand specimen by deionized water passing of 2 volume pore voids, $\mathrm{Vv}$ which about 140 $\mathrm{ml}$.

b. $1.5 \mathrm{Vv}$ of bacterial cell solution was injected with a pressure head of $1 \mathrm{~m}$ with dropping slightly and drainage rate $10 \mathrm{ml} / \mathrm{min}$ from bottom specimen by a peristaltic pump as shown in Figure (4 a).

c. After completely saturated specimen with bacterial cell, the flow ended for 12 hours period to allow the bacterial cells attached on sand particles. Once the retention time ended detach the peristaltic pump to discharge the solution by gravity.

d. A vessel of reagent solutions (Urea-CaCl 2$)$ which is lighter density than bacterial solution, were placed directly over the specimen (no pressure head) with drainage $3 \mathrm{ml} / \mathrm{h}$ from the bottom of the specimen as shown in Figure (4 b).

e. After reagent solution insertion of volume $1 \mathrm{Vv}$, the flow was ceased for 24 hours to let bacteria react with the reagent solution. Next, the peristaltic pump was detached from the line and accepts the solution 
to discharge by gravity and repeat the later for various time and concentrations.



Figure (3): Clear acrylic column for soil treatment

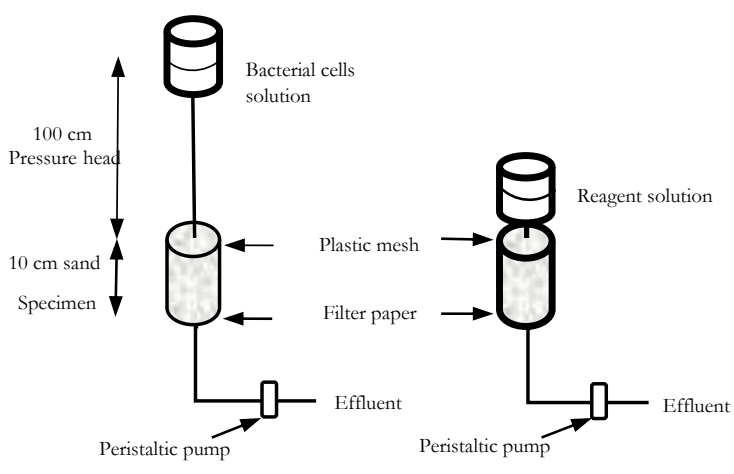

(a)

(b)

Figure (4): The bacterial and reagent solutions injection protocol: (a) injection of bacterial cells solution; (b) injection of reagent solution.

\subsection{Permeability Examination}

The relative change of the hydraulic conductivity was monitored through the same sand column. Falling head test has been utilized to measure the coefficient of permeability development through experiment duration (ASTM D 5856-15). Water flows across the sand sample via stand pipe joined to the top of sample cell column; as shown in Figure (5).

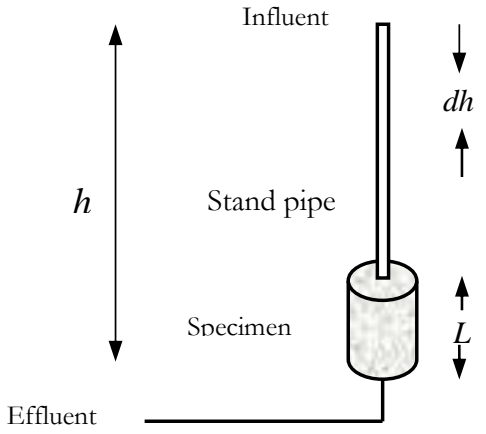

Figure (5): schematic draw for soil sample hydraulic conductivity test (variable head).

The water head $(\mathrm{h})$ change over with time as flow take place across the sand specimen. Head of water is recorded at various times as follow:

$$
K=\frac{(a \times L)}{A\left(t_{2}-t_{1}\right) \ln \left(\frac{h_{1}}{h_{2}}\right)}
$$

Where: $\mathrm{t}=$ time; $\mathrm{L}=$ length of sand column; $\mathrm{A}=$ cross section area of sand; $\quad \mathrm{a}=$ cross section area of stand pipe and $\mathrm{K}=$ coefficient of permeability.

\section{Results and Discussion \\ 5.1 Bacteria Concentration}

Three groups of sand columns specimens were injected in different S. Pasteurii bacteria cells concentration solution. The $\mathrm{OD}_{600}$ values were high (1.3), medium (0.5) and low (0.2) to find out the optimum bacteria cells concentration to achieve biocementation. Specimens were tested for three days and the results as shown in Figure (6), the $\mathrm{pH}$ value for high concentrated bacteria (1.3) has convex trend due to fermentation of microorganisms which raise the acidity as well dissolve carbonates and hydroxides binding sand grains. Also the high concentration of organic species may produce the slime which lubricates sand particles and caused reduction in internal friction angle. The reduction in hydraulic conductivity causes microorganisms accumulation between sand pores rather than calcite precipitation. Low bacteria cells concentration (0.2) treatment pretends no significant change in tests results. However, the $\mathrm{OD}_{600}$ value of 0.5 shows sufficient urease activity represented by increasing in electrical conductivity also the internal friction angle of treated specimens which tested by direct shear method and was enhanced due to calcite precipitation on sand particles and reduces the permeability as shown in Figure (6).

\subsection{Bacteria Number of Injections}

A comparison was carried out to investigate the suitable time's number of bacteria cells injection influence on sand specimens. Two injection criteria was adopted in the experiment which lasted four days; single bacteria cells injection at the beginning of the test and multi injection times, dual injection, conducted every 48 hours along testing duration. Results were illustrated that multi injection procedure has notable development for the same experiment duration (four days). A slight decreasing in hydraulic conductivity attributed to the development of calcite precipitation indicated by the increasing of urease activity (electrical conductivity). The $\mathrm{pH}$ values were almost coupled; however the internal friction angle has increased fairly as shown in Figure (7). The multi injection procedure will keep the average of urease production at levels initiate continuous cementation by calcite precipitation on sand particles. However, the injection of bacteria cells without nutrient to prevent increasing in biomass, which could potentially plug the pores by biomass instead of calcite precipitation, Tobler et al. [14]. The plugging occurs by biomass will prevent the distribution of bacteria cells. Furthermore, the growth of biomass may reduce the $\mathrm{pH}$ solution and may delay urea hydrolysis and mineral precipitations as demonstrated in Figure (6). 


\subsection{Strength Development}

One of the intentions of this study is to examine the potential of S.Pasteurii to perform as an ingredient for making bio cement. Soft rocks were made by dispersing the bacteria cells in situ within 48 hours treatments of successive injecting of bacteria pursued by cementation solution (urea/calcium)
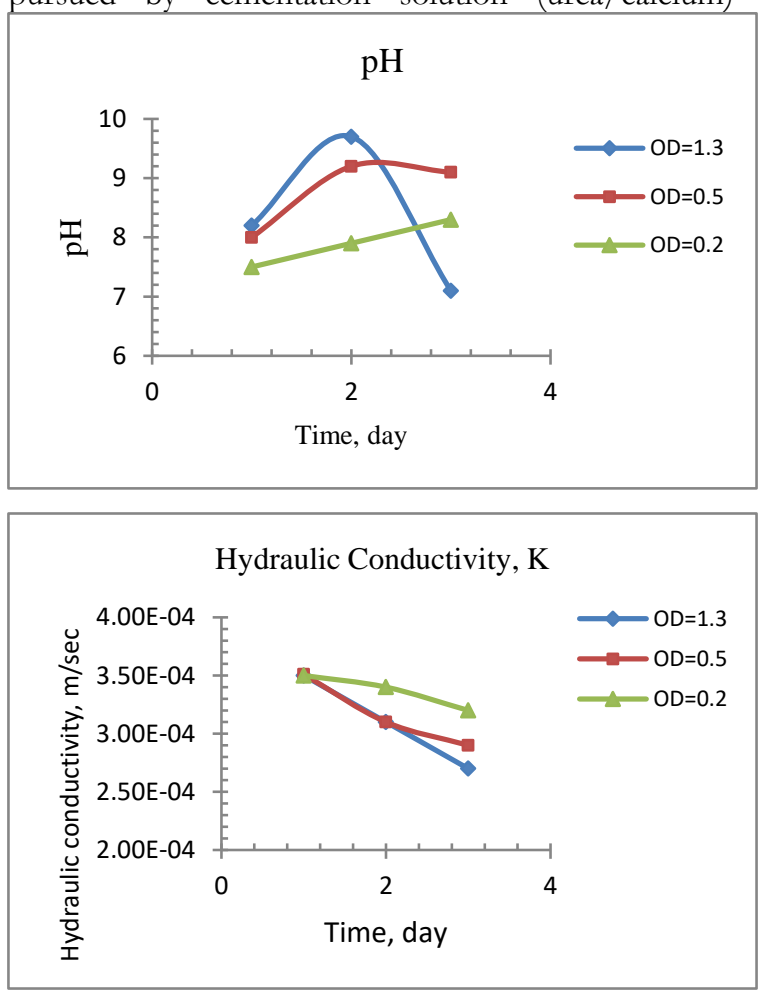

Figure (6): Results of $\mathrm{pH}$, electrical conductivity, permeability and internal friction angle for sand column specimens treated by three different bacteria concentrations.
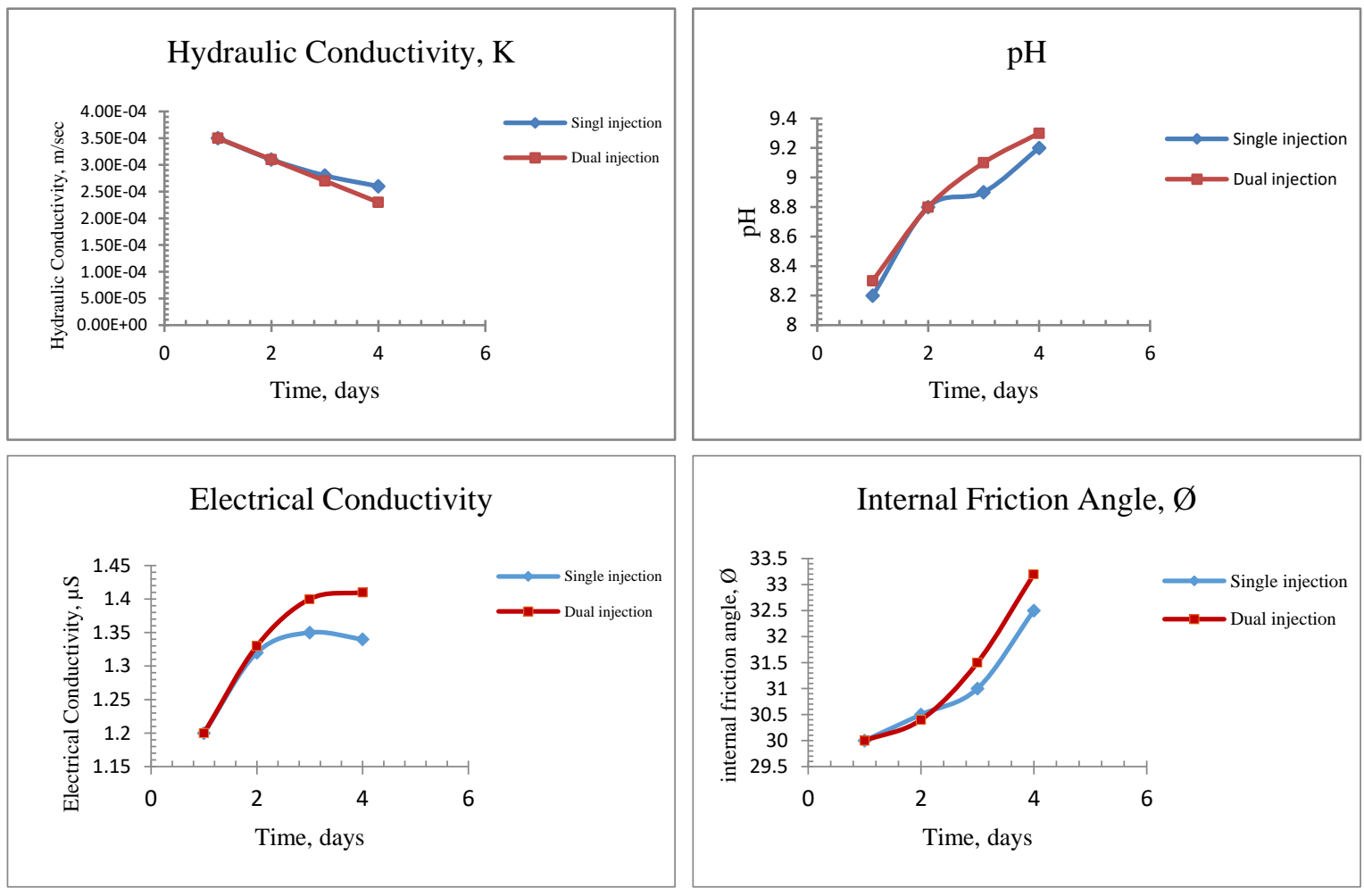

Figure (7): Results of $\mathrm{pH}$, electrical conductivity, permeability and internal friction angle for sand column specimens with different injection criteria 
Unconfined compressive strength test was carried out on column specimens to verify the mechanical properties of cemented sand. A bacteria cells concentration with $\mathrm{OD}_{600}=0.5$ was adopted as tested previously. The reagent solution concentration was $1 \mathrm{M}$ urea and $1 \mathrm{M}$ calcium chloride (Urea molarity1.85 times that of calcium chloride) as best ratio accepted from previous literatures Whiffin et al.[4], O'kelly et al.[22] . As shown in Figure (9) the sand strength grows exponentially with treatment time with maximum strength $1.03 \mathrm{MPa}$ in 60 days. The classification system implemented in this study was built on that established by Shafii and Clough [24], where softly cemented sand was described as requiring a UCS of fewer than $0.3 \mathrm{MPa}$, moderate cemented sand was described as holding a UCS between $0.4 \mathrm{MPa}$ and $1 \mathrm{MPa}$ and solidified sand was for that greater than $1 \mathrm{MPa}$.

Figure (10) shows the strength variance between specimens of sand prepared with two different injected substances corresponding bacteria cells with reagent solution $\left(\mathrm{CaCl}_{2} /\right.$ urea $)$ only, and without the reagent solution (bacteria cells only) for period of 5 days.

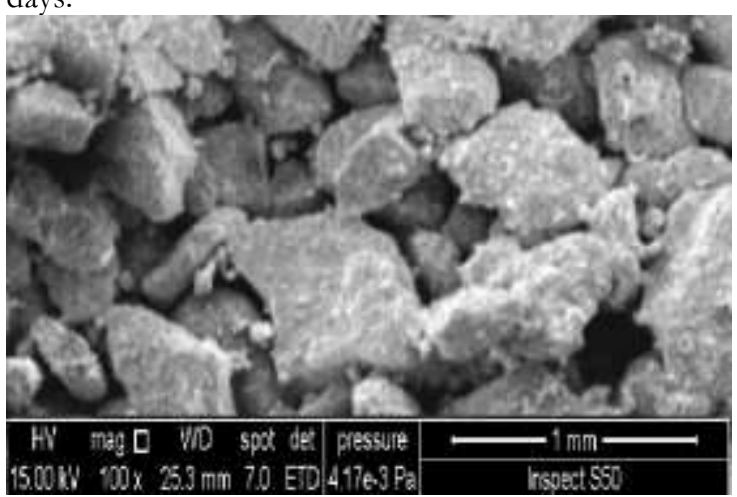

Figure (8): SEM image for bond point-to-point contact between adjacent sand particles made by calcite precipitation.

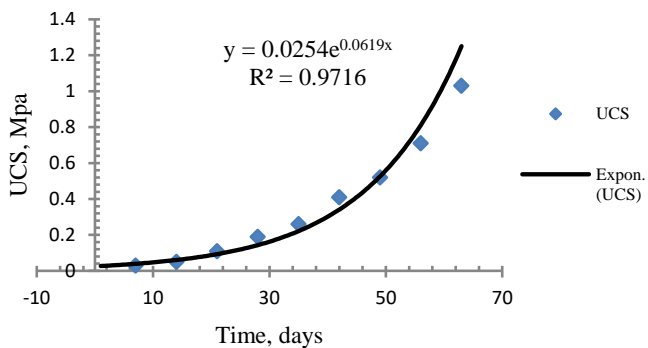

Figure (9): strength developments with time for the sand specimens' column

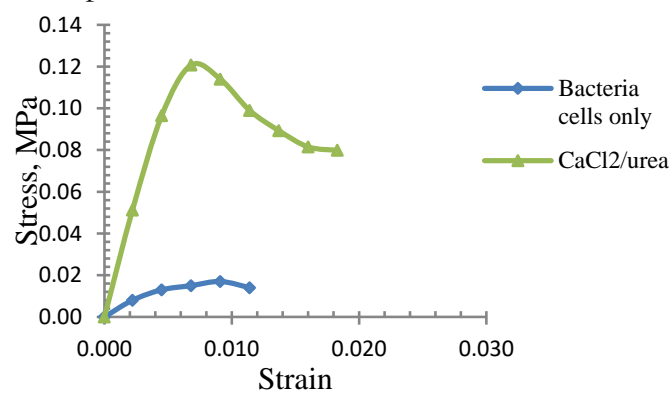

Figure (10): UCS results for different injected materials with S.Pasteurii bacteria cells in column sand specimens.
From the preceding figure it is obviously clear that the effect of reagent solution presence enhances about 5 times the cementation procedure due to calcite bio precipitation on sand particles.

\subsection{Hydraulic Conductivity}

Permeability tests were carried out on a set of compacted sand column specimens. The bacteria and reagent solution injection procedure were the same as mentioned previously. The results illustrated a significant reduction with specific specimens permeability during the period of test which last for 14 days, whereas another specimens barely their permeability is reduced. Figure (11) shows the reaction variance of bacteria cells when some species added to the reagent solution, while no mentioned drop in permeability in the absence of reagent solution. The specimens injected with bacteria cells only has no action except the accumulation of some cells body in pore spaces due to lack of urease production to complete the precipitation action. However, the existence of reagent solution catalyzes the S. Pasteurii bacteria cells to produce urease. Calcium or lead free ions start to precipitate as carbonates on pores throat of sand grains in which reduces the flow through these minor channels. The decrease in hydraulic conductivity of processed sand specimens was about 3.6 times with the presence of reagent solution.

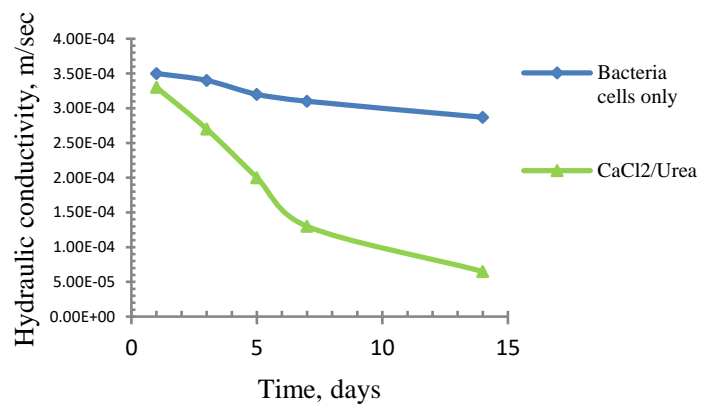

Figure (11): The permeability variance of sand column specimens with different reagent solution combinations.

\section{Conclusion}

According to the results attained from the experimental work, some conclusions can be extracted:

The column specimen results show that the best bacteria concentration $\mathrm{OD}_{600}$ was 0.5 for durable bio precipitation process by injecting live bacteria cells only without adding nutrient to prevent uncontrolled colonies augmentations. Further minerals precipitation occurs when the bacteria had multiple injection number with medium $\mathrm{OD}_{600}$ than one with high $\mathrm{OD}_{600}$ which may raise the site acidity and affect inversely on precipitation process (lowering the $\mathrm{pH}$ value less than 7). The results of UCS strengths determined in this paper have revealed significant increment with time from zero up to $1.03 \mathrm{MPa}$ with controlled environment in column specimen, $\mathrm{pH}$, and temperature Results of hydraulic conductivity 
illustrate a good reduction due to calcite precipitation and clogging the pore space between sand grains.

\section{References:}

[1] Fujita, Y., J. Taylor, L. Wendt, D. Reed, and R. Smith (2010), Evaluating the potential of native ureolytic microbes to remediate a (90)sr contaminated environment, Environ. Sci. Technol., 44(19), 76527658 .

[2] DeJong, J. T. (2006), Microbially induced cementation to control sand response to undrained shear, J. Geotech. Geoenviron. Eng., 132(11), 1381.

[3] van Paassen, L. A., R. Ghose, T. J. M. van der Linden, W. R. L. van der Star, and M. C. M. van Loosdrecht (2010), Quantifying biomediated ground improvement by ureolysis: Large-scale biogrout experiment, J. Geotech. Geoenviron. Eng., 136(12), 1721-1728.

[4] Whiffin, V. S., L. A. van Paassen, and M. P. Harkes (2007), Microbial carbonate precipitation as a soil improvement technique, Geomicrobiol. J., 24(5), 417-423.

[5] Cunningham, A. B., R. Gerlach, L. Spangler, and A. C. Mitchell (2009), Microbially enhanced geologic containment of sequestered supercritical $\mathrm{CO}_{2}$, Energy Procedia, 1(1), 3245-3252.

[6] Ferris, F., V. Phoenix, Y. Fujita, and R. Smith (2003), Kinetics of calcite precipitation induced by ureolytic bacteria at 10 to 20 degrees $\mathrm{C}$ in artificial groundwater, Geochim. Cosmochim. Acta, 67(8), 1701-1710.

[7] Mobley, H. L. T., and R. P. Hausinger (1989), Microbial ureases-significance, regulation, and molecular characterization, Microbiol. Rev., 53(1), 85-108.

[8] Stumm, W., and J. J. Morgan (1996), Aquatic Chemistry: Chemical Equilibria and Rates in Natural Waters, 3rd ed., xvi, 1022 pp., Wiley, N. Y.

[9] Fujita, Y., J. L. Taylor, T. L. T. Gresham, M. E. Delwiche, F. S. Colwell, T. L. McLing, L. M. Petzke, and R. W. Smith (2008), Stimulation of microbial urea hydrolysis in groundwater to enhance calcite precipitation, Environ. Sci. Technol., 42(8), 30253032.

[10] Harkes, M. P., L. A. van Paassen, J. L. Booster, V. S. Whiffin, and M. C. M. van Loosdrecht (2010), Fixation and distribution of bacterial activity in sand to induce carbonate precipitation for ground reinforcement, Ecol. Eng., 36(2), 112-117.

[11] De Muynck, W., K. Verbeken, N. De Belie, and W. Verstraete (2010b), Influence of urea and calcium dosage on the effectiveness of bacterially induced carbonate precipitation on limestone, Ecol. Eng., 36(2), 99-111.

[12] Mohammed A., Al-Omarib R., Mustafa H., (2017), Experimental Study to Improve the Shear Stress of Silty- Sandy Soils by Using Urease Producing Bacteria, American Scientific Research Journal for Engineering, Technology, and Sciences (ASRJETS) ISSN (Print) 2313-4410, ISSN (Online) 2313-4402

[13] Achal, V., A. Mukherjee, P. C. Basu, and M. S. Reddy (2009b), Strain improvement of Sporosarcina pasteurii for enhanced urease and calcite production, J. Ind. Microbiol. Biotechnol., 36(7), 981-988.

[14] Tobler, D. J., M. O. Cuthbert, R. B. reswell, M. S. Riley, J. C. Renshaw, S. Handley-Sidhu, and V. R. Phoenix (2011), Comparison of rates of ureolysis between Sporosarcina pasteurii and an indigenous groundwater community under conditions required to precipitate large volumes of calcite, Geochim. Cosmochim. Acta, 75(11), 3290-3301, doi:10.1016/ j.gca.2011.03.023.

[15] DeJong, J. T., K. Soga, S. A. Banwart, W. R. Whalley, T. R. Ginn, D. C. Nelson, B. M. Mortensen, B. C. Martinez, and T. Barkouki (2012), Soil engineering in vivo: Harnessing natural biogeochemical systems for sustainable, multifunctional engineering solutions, J. R. Soc., Interface, 8(54), 1-15.

[16] Ramachandran SK, Ramakrishnan V, Bang SS (2001), Remediation of concrete using microorganisms. ACI Mater J 98:3-9

[17] Ferris, F., L. Stehmeier, A. Kantzas, and F. Mourits (1996), Bacteriogenic mineral plugging, J. Can. Petrol. Technol., 35, 56-61.

[18] Inagaki, Y., Tsukamoto, M., Mori, H., Sasaki, T., Soga, K., Al. Qabany, A., Hata, T., 2011. The influence of injection conditions and soil types on soil improvement by microbial functions. ASCE, Geo-Frontiers.4021-4030.

[19] Mitchell JK and Santamarina JC (2005) Biological considerations in geotechnical engineering. Geotechnical and Geoenvironmental Engineering 131(10): 1222-1233.

[20] Rebata-Landa V (2007) Microbial Activity in Sediments: Effects on Soil Behavior. PhD thesis, Georgia Institute of Technology, Atlanta, GA, USA.

[21] Ciurli, S., C. Marzadori, S. Benini, S. Deiana, and C. Gessa (1996), Urease from the soil bacterium Bacillus pasteurii: Immobilization on Capolygalacturonate, Soil Biol. Biochem., 28(6), 811817.

[22] O'Kelly Brendan, Rahim Shahrokhi, Seyed M. Zomorodian and Ali Niazi (2015) Improvement Sand with Microbial Induced Carbonate Precipitation, institute of cicil engineering, v168(3), 1755-0750.

[23] Sharma, S.S., and Fahey, M. (2003b). Evaluation of Cyclic Shear Strength of Two Cemented Calcareous Soils. Journal of Geotechnical and Geo environmental engineering 608-618.

[24] Shafii, R.-N., Clough, W., 1982. The Influence of Cementation on the Static and Dynamic Behavior of Sands. Stanford, California, California. 